\title{
ANALISIS KEANDALAN MESIN PRODUKSI TISSUE BASAH
}

\author{
Dwi Hadi Sulistyarini \\ Dosen \\ Universitas Brawijaya \\ Jurusan Teknik Industri \\ ewiek.dhs@gmail.com \\ Putu Hadi Setyarini \\ Dosen \\ Universitas Brawijaya \\ Jurusan Teknik Mesin \\ putu_hadi@ub.ac.id
}

\section{Amanda Nur Cahyawati \\ Dosen \\ Universitas Brawijaya Jurusan Teknik Industri an.cahyawati@ub.ac.id}

\begin{abstract}
The wet tissue company in this research has 46 volpack machines, 44 are used to produce wet sanitizer tissue and 2 other machines are used to produce wet cologne tissue. During this time, the company produces cologne type wet tissue where its production does not reach the production target. One of the causes of this problem was the high downtime influenced by the reliability of these components and machine; so causing the production capacity of wet cologne tissue to be reduced and company's production targets not achieved. Therefore, in order to achieve the company's production targets and to make the production process more efficient and effective, it is necessary a good maintenance actions that pay attention to the reliability value of each critical component. This study analyzes the reliability of critical components so that companies can take action to increase their machine reliability.
\end{abstract}

Keywords: Reliability, Preventive Maintenance

\section{PENDAHULUAN}

Perusahaan yang bergerak dibidang manufaktur di Indonesia setiap hari berkembang dengan pesatnya. Hal ini tentu saja menyebabkan persaingan antar perusahaan yang bergerak dibidang manufaktur di Indonesia akan semakin tinggi. Tentu saja setiap perusahaan yang bergerak dibidang manufaktur tidak menginginkan kekalahan dalam persaingan.Salah satu contoh perusahaan yang sedang berkembang saat ini adalah perusahaan tissue basah.

Tanpa disadari, tissue basah sudah menjadi kebutuhan tambahan yang dibutuhkan oleh manusia. Agar perusahaan manufaktur dapat melakukan proses produksi dengan lancar, tentu saja banyak hal yang harus diperhatikan. Mulai dari manajemen produksinya, manajemen persediaan bahan baku, hingga manajemen perawatan yang diterapkan oleh perusahaan. Salah satu hal yang sangat mempengaruhi kelancaran proses produksi pada perusahaan manufaktur adalah manajemen perawatannya. Dalam hal ini, manajemen perawatan berkaitan dengan kegiatan perawatan yang dilakukan terhadap mesin-mesin yang digunakan untuk melakukan proses produksi agar proses produksi berjalan efektif dan efisien.

Salah satu faktor yang mempengaruhi kelancaran produksi pada setiap perusahaan manufaktur adalah kondisi mesin yang masih andal atau tidak. Keandalan (Reliability) didefinisikan sebagai probabilitas suatu item dalam menjalankan fungsinya secara memuaskan selama periode waktu tertentu dan digunakan atau dioperasikan dalam kondisi yang semestinya[6]. Jika kondisi mesin dalam keadaan tidak andal atau buruk, maka tentu saja bisa mempengaruhi kelancaran produksi perusahaan, salah satunya bisa menyebabkan defect pada produk yang dihasilkan. Namun sebaliknya, jika kondisi mesin dalam keadaan baik, maka tentu saja hasil produksinya bisa maksimal. Maka dari itu, kondisi mesin yang baik dan andal sangat dibutuhkan oleh perusahaan. Salah satu cara agar kondisi mesin dalam keadaan baik dan andal adalah dengan melakukan maintenance yang rutin. fungsi maintenance adalah agar dapat memperpanjang umur ekonomis dari mesin atau peralatan produksi yang ada serta mengusahakan agar mesin dan peralatan produksi tersebut selalu dalam keadaan optimal dan siap pakai untuk pelaksanaan proses produksi[1].

Perusahaan tissue basah disini mempunyai 2 jenis tissue sebagai hasil proses produksi yang utama yaitu tissue basah sanitizer dan tissue basah cologne. Jumlah mesin hingga saat ini yang dimiliki untuk memproduksi tissue basah adalah sebanyak 46 unit mesin. Total mesin yang digunakan untuk melakukan produksi tissue basah sanitizer adalah 44 unit dan total mesin yang digunakan untuk melakukan produksi tissue basah cologne adalah 2 unit yang umur mesinnya telah mencapai lebih dari 10 tahun. Dengan permintaan yang tinggi dan tidak di imbangi oleh jumlah mesin yang maksimal, mesin produksi cologne tentu saja bisa mengalami downtime sewaktu-waktu dan menyebabkan perusahaan mengalami kerugian. Maka dari itu, agar bisa mengimbangi permintaan yang tinggi dengan jumlah mesin yang minimal dan mengatasi kemungkinan terjadi downtime yang tinggi, perusahaan harus mempunyai sistem maintenance yang baik. Sistem maintenance yang baik adalah saat perusahaan mempunyai jadwal maintenance rutin yang harus dilakukan agar mencegah mesin 
mengalami downtime sewaktu-waktu. Selain itu, dengan mempunyai kegiatan maintenance yang rutin, perusahaan bisa menjaga mesin tetap andal sehingga produk yang dihasilkan lebih maksimal. Sistem perbaikan atau maintenance yang diterapkan pada perusahaan ini adalah sistem corrective maintenance yaitu dilakukan saat komponen mesin sudah mengalami kerusakan yang dilakukan saat downtime yang terjadi secara mendadak.

Tabel 1. Perbandingan Hasil Produksi Tissue Basah Cologne dengan Target Produksi Maret - Desember 2016

\begin{tabular}{ll}
\hline Hasil produksi & Target yang ditetapkan \\
\hline $10.530 .600 \mathrm{pcs}$ & $11.120 .400 \mathrm{pcs}$ \\
\hline
\end{tabular}

Dari Tabel 1 didapati bahwa jumlah produksi yang dihasilkan berselisih jauh dengan target yang ditetapkan perusahaan. Hal ini menyebabkan perusahaan mengalami kerugian. Salah satu penyebab jumlah produksi yang tidak sesuai target perusahaan adalah tingkat frekuensi downtime mesin yang tinggi yang ditunjukkan dalam Tabel 2.

Tabel 2. Frekuensi Downtime Mesin Volpack Produksi Tissue Basah Cologne Maret - Desember 2016

\begin{tabular}{lccc}
\hline Bulan & Frekuensi & $\begin{array}{c}\text { Total Waktu } \\
\text { Downtime (menit) }\end{array}$ & $\begin{array}{c}\text { Besarnya kehilangan tissue } \\
\text { (pcs) }\end{array}$ \\
\hline Maret & 9 & 465 & 55800 \\
April & 11 & 595 & 71400 \\
Mei & 11 & 540 & 64800 \\
Juni & 10 & 520 & 62400 \\
Juli & 10 & 465 & 55800 \\
Agustus & 9 & 440 & 52800 \\
September & 9 & 425 & 51000 \\
Oktober & 8 & 435 & 52200 \\
November & 10 & 530 & 63600 \\
Desember & 10 & 500 & 60000 \\
\hline Jumlah & 97 & 4915 & 589800 \\
\hline
\end{tabular}

Penyebab frekuensi downtime yang tinggi, tentu saja tidak sertamerta berasal dari tingkat utilitas mesin yang tinggi, namun bisa saja berasal dari mesin itu sendiri yang keandalannya mulai berkurang. Keandalan mesin yang mulai berkurang juga disebabkan oleh keandalan komponen mesin tersebut yang mulai berkurang. Dengan kata lain, salah satu penyebab frekuensi downtime yang tinggi yang terjadi secara tiba-tiba sehingga menyebabkan tidak sesuainya antara jumlah produksi dan target produksi perusahaan adalah keandalan komponen yang rendah yang mempengaruhi keandalan mesin. Dapat dipastikan dengan mempunyai tingkat keandalan yang rendah, mesin tersebut akan mengalami downtime. Untuk meminimasi hal tersebut, maka tentu saja perusahaan harus mempunyai system maintenance mesin yang baik sehingga bisa meningkatkan keandalan mesin dan komponen sehingga mengurangi frekuensi downtime yang terjadi secara tiba-tiba.

\section{METODE PENELITIAN}

Pada penelitian ini data yang dikumpulkan oleh peneliti meliputi data fungsi komponen-komponen mesin volpack, data komponen mesin volpack yang sering mengalami kerusakan, data frekuensi kerusakan komponen mesin volpack dan data waktu downtime mesin volpack. Pengumpulan data diatas dilakukan dengan melakukan pengamatan langsung di lapangan dan melakukan pencatatan data yang didapat dari maintenance report perusahaan. Sehingga dari data-data tersebut dapat dilakukan penelitian mengenai analisis keandalan mesin volpack.

Pengolahan data pada penelitian ini dimulai dengan melakukan pemilihan komponen kritis mesin volpack dengan menggunakan diagram pareto. Selanjutnya menghitung time to failure dari tiap komponen kritis mesin volpack. Selanjutnya, dilakukan pendugaan distribusi dengan menghitung nilai index of fit distribusi weibull, lognormal, dan normal dari tiap komponen kritis.

Setelah mendapatkan bentuk distribusinya, maka dilanjutkan dengan pengujian goodness of fit dengan uji statistik. Uji statistik yang digunakan adalah kolmogorov-smirnov untuk data yang berdistribusi lognormal atau normal, man's test untuk data yang berdistribusi weibull. Tujuan goodness of fit adalah agar memastikan data benar berdistribusi sesuai dugaan awal.

Tahapan yang dilakukan berikutnya adalah perhitungan parameter distribusi sesuai distribusi yang terpilih. Setelah mendapatkan nilai parameter tiap distribusinya, maka langkah selanjutnya adalah melakukan perhitungan keandalan komponen kritis mesin volpack. 


\section{HASIL DAN DISKUSI}

Pengolahan data dilakukan dengan menentukan komponen kritis hingga melakukan perhitungan keandalan mesin volpack, penjabaran pengolahan data sebagai berikut :

1. Pemilihan Komponen Kritis

Pemilihan komponen kritis dari mesin volpack dengan melihat frekuensi downtime dari komponen tersebut. Berikut adalah data frekuensi kerusakan komponen mesin volpack produksi cologne yang ditunjukkan dalam tabel 3.

Tabel 3. Frekuensi Kerusakan Komponen Mesin Volpack Produksi Tissue Cologne Maret - Desember 2016

\begin{tabular}{lc}
\hline Komponen & $\begin{array}{c}\text { Frekuensi } \\
\text { Kerusakan }\end{array}$ \\
\hline O-Ring & 20 \\
Pisau foil I & 13 \\
Pisau foil L & 14 \\
Klep pipa & 12 \\
Seal heater & 13 \\
Rantai & 5 \\
Ring 6 & 6 \\
Ring 8 & 5 \\
Corong kertas & 3 \\
Per pisau foil I dan L & 6 \\
\hline Jumlah & 97 \\
\hline
\end{tabular}

Tabel 3 dapat dibuat pareto chart untuk mengetahui komponen yang mempunyai frekuensi downtime tertinggi hingga terendah (Gambar 4). Dari diagram tersebut komponen kritis dari mesin volpack dapat kita tentukan.

Pemilihan komponen kritis dalam penelitian ini menggunakan prinsip pareto yaitu $80: 20$, yang berarti menyelesaikan $20 \%$ masalah yang ada agar mendapatkan efek sebesar $80 \%$. Dari gambar 4 dapat dilihat bahwa komponen yang berada dalam rentan cumulative $80 \%$ adalah komponen O-Ring, Pisau foil I, Pisau foil L, Seal heater, Klep pipa, dan pir pisau foil I dan L. Sehingga dapat disimpulkan bahwa komponen kritis yang harus diselesaikan adalah komponen O-Ring, Pisau foil I, Pisau foil L, Seal heater, Klep Pipa, dan Per Pisau foil I dan L.

\section{Perhitungan Index of fit}

Perhitungan index of fit dilakukan pada setiap komponen kritis berdasarkan 3 distribusi yaitu weibull, normal, dan lognormal. Perhitungan index of fit menggunakan rumus correlation coeficient dengan metode Least Square. Distribusi yang terpilih adalah distribusi dengan nilai index of fit terbesar. Hasil perhitungan index of fit dapat dilihat pada tabel 4 .

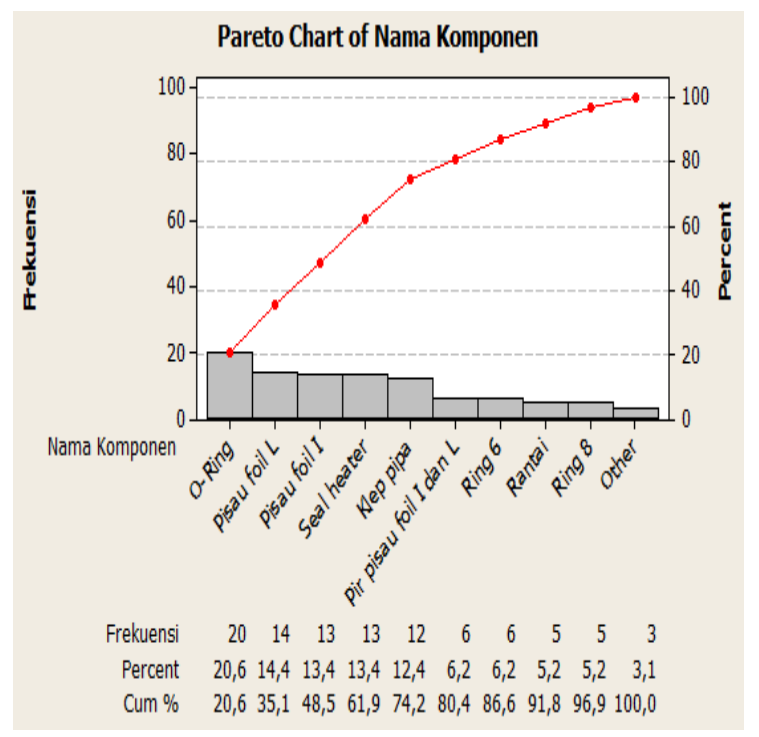

Gambar 1. Pareto Chart Komponen Mesin Volpack Produksi Tissue Basah Cologne 
Tabel 4. Perhitungan Index of fit

\begin{tabular}{lcccccc}
\hline & \multicolumn{7}{c}{ Komponen } \\
\cline { 2 - 7 } & $\begin{array}{c}\text { O- } \\
\text { Ring }\end{array}$ & $\begin{array}{c}\text { Klep } \\
\text { pipa }\end{array}$ & $\begin{array}{c}\text { Seal } \\
\text { Heater }\end{array}$ & $\begin{array}{c}\text { Pisau } \\
\text { foil I }\end{array}$ & $\begin{array}{c}\text { Pisau } \\
\text { foil L }\end{array}$ & $\begin{array}{c}\text { Pir Pisau } \\
\text { Foil I dan L }\end{array}$ \\
\cline { 2 - 7 } Weibull & 0,977 & 0,961 & 0,951 & 0,891 & 0,984 & 0,945 \\
Log Normal & 0,948 & 0,992 & 0,959 & 0,946 & 0,985 & 0,950 \\
Normal & 0,981 & 0,973 & 0958 & 0,905 & 0,986 & 0,946 \\
\hline
\end{tabular}

Contoh perhitungan index of fit untuk komponen pir pisau foil I dan L distribusi weibull :

Tabel 5. Perhitungan Index of fit Distribusi Weibull Komponen Pir Pisau Foil I dan L

\begin{tabular}{lccc}
\hline $\mathrm{i}$ & $\mathrm{Ti}$ & $\mathrm{Xi}$ & $\mathrm{Yi}$ \\
\hline 1 & 274,5 & 5,614 & $-1,974$ \\
2 & 335 & 5,814 & $-0,9726$ \\
3 & 339 & $5,, 82$ & $-0,366$ \\
4 & 348 & 5,85 & 0,144 \\
5 & 423,5 & 6,04 & 0,7144 \\
\hline Jumlah & 1720 & 29,155 & $-2,454$ \\
\hline
\end{tabular}

$\mathrm{x}_{\mathrm{i}}=\ln \mathrm{t}_{\mathrm{i}}$

(Pers. 1)

$F\left(t_{i}\right)=\frac{i-0,3}{n+0,4}$

(Pers. 2)

$F\left(t_{1}\right)=\frac{1-0,3}{5+0,4}=0,1296296$

$\mathrm{y}_{\mathrm{i}}=\ln \left[\ln \left(\frac{1}{1-F\left(t_{i}\right)}\right)\right]$

(Pers. 3)

$\mathrm{y}_{1}=\ln \left[\ln \left(\frac{1}{1-0,1296296}\right)\right]=-1,97445869$

Nilai index of fit :

$r=\frac{n \sum_{i=1}^{n} x i . y i-\left(\sum_{i=1}^{n} x i\right)\left(\sum_{i=1}^{n} y i\right)}{\sqrt{\left[n \sum_{i=1}^{n} x i^{2}-\left(\sum_{i=1}^{n} x i\right)^{2}\right]\left[n \sum_{i=1}^{n} y i^{2}-\left(\sum_{i=1}^{n} y i\right)^{2}\right.}}$

(Pers. 4)

$r=\frac{(5)(-13,708)-(29,155)(-2,4544)}{\sqrt{[(5)(170,107)-(29,155)(29,155)][(5)(5,5103)-(-2,454)}(-2,4544)]}$

$r=0,945$

Contoh perhitungan index of fit untuk komponen pir pisau foil I dan L distribusi lognormal :

Tabel 6. Perhitungan Index of fit Distribusi Normal Komponen Pir Pisau Foil I dan L

\begin{tabular}{llll}
\hline $\mathrm{i}$ & $\mathrm{Ti}$ & $\mathrm{Xi}$ & $\mathrm{Zi}$ \\
\hline 1 & 274,5 & 5,614 & $-1,12$ \\
2 & 335 & 5,814 & $-0,482$ \\
3 & 339 & 5,82 & 0 \\
4 & 348 & 5,85 & 0,482 \\
5 & 423,5 & 6,04 & 1,12 \\
\hline Jumlah & 1720 & 29,155 & 0 \\
\hline
\end{tabular}

$\mathrm{x}_{\mathrm{i}}=\ln \mathrm{t}_{\mathrm{i}}$

(Pers. 5)

$F\left(t_{i}\right)=\frac{i-0,3}{n+0,4}$

(Pers. 6)

$F\left(t_{1}\right)=\frac{1-0,3}{4+0,4}=0,1296296$

$z_{i}=$ diperoleh dari tabel $\mathrm{z}$ (normal)

Nilai index of fit :

$r=\frac{n \sum_{i=1}^{n} x i . z i-\left(\sum_{i=1}^{n} x i\right)\left(\sum_{i=1}^{n} z i\right)}{\sqrt{\left[n \sum_{i=1}^{n} x i^{2}-\left(\sum_{i=1}^{n} x i\right)^{2}\right]\left[n \sum_{i=1}^{n} z i^{2}-\left(\sum_{i=1}^{n} z i\right)^{2}\right.}}$

(Pers. 7) 
$r=\frac{(5)(0,5074)-(29,15)(0)}{\sqrt{[(5)(170,107)-(29,15)(29,15)][(5)(3,01)-(0)}(0)]}$

$\mathrm{r}=0,950$

Dari perhitungan index of fit didapatkan bahwa komponen O-Ring dan pisau foil L berdistribusi normal dan komponen klep pipa, seal heater, pisau foil I dan pir pisau foil I dan L berdistribusi lognormal.

\section{Pengujian Goodness of fit}

Pengujian Goodness of fit bertujuan untuk memastikan data benar-benar sesuai dengan dugaan distribusi awal. Pengujian goodness of fit dilakukan dengan melakukan uji statistik Kolmogorov-Smirnov karena data berdistribusi normal dan lognormal. Hasil pengujian diterima saat nilai Kolmogorov-Smirnov dari perhitungan lebih kecil dari nilai yang ada pada tabel Kolmogorov-Smirnov. Dalam pengujian ini, nilai alfa yang digunakan adalah $1 \%$ atau 0,01 .

Hasil pengujian menunjukkan bahwauntuk semua komponen mempunyai nilai Kolmogorov Smirnov yang lebih kecil dari tabel, sehingga didapatkan bahwa data memang benar berdistribusi normal dan lognormal. Hipotesis :

$\mathrm{H}_{\mathrm{o}}=$ Data waktu komponen berdistribusi lognormal atau normal

$\mathrm{H}_{1}=$ Data waktu komponen tidak berdistribusi Lognormal atau normal

Tabel 7. Hasil Goodness of fit

\begin{tabular}{lll}
\hline Komponen & Hasil & \\
\hline O-Ring & $D_{\text {hitung }}<\mathrm{D}_{\text {tabel }}$ & $\mathrm{H}_{\mathrm{o}}$ diterima \\
Klep pipa & $\mathrm{D}_{\text {hitung }}<\mathrm{D}_{\text {tabel }}$ & $\mathrm{H}_{\mathrm{o}}$ diterima \\
Seal heater & $\mathrm{D}_{\text {hitung }}<\mathrm{D}_{\text {tabel }}$ & $\mathrm{H}_{\mathrm{o}}$ diterima \\
Pisau foil I & $\mathrm{D}_{\text {hitung }}<\mathrm{D}_{\text {tabel }}$ & $\mathrm{H}_{\mathrm{o}}$ diterima \\
Pisau foil L & $\mathrm{D}_{\text {hitung }}<\mathrm{D}_{\text {tabel }}$ & $\mathrm{H}_{\mathrm{o}}$ diterima \\
Pir Pisau foil I & $\mathrm{D}_{\text {hitung }}<\mathrm{D}_{\text {tabel }}$ & $\mathrm{H}_{\mathrm{o}}$ diterima \\
dan L & & \\
\hline
\end{tabular}

\section{Perhitungan Parameter Distribusi}

Perhitungan parameter distribusi dilakukan dengan mencari nilai-nilai parameter dari tiap distribusi yang ada pada tabel 8. Nilai dari parameter distribusi ini digunakan untuk menentukan nilai keandalan dari tiap komponen kritisnya.

Tabel 8. Perhitungan Parameter Distribusi

\begin{tabular}{|c|c|c|c|}
\hline Komponen & Distribusi & Parameter & \\
\hline O-Ring & Normal & $\begin{array}{l}\text { Mean } \\
\text { Variance }\end{array}$ & $\begin{array}{r}113,66 \\
1965,86 \\
\end{array}$ \\
\hline Klep pipa & Lognormal & $\begin{array}{l}\text { Shape } \\
\text { Location }\end{array}$ & $\begin{array}{l}0,27 \\
5,21 \\
\end{array}$ \\
\hline Seal heater & Lognormal & $\begin{array}{l}\text { Shape } \\
\text { Location }\end{array}$ & $\begin{array}{l}0,47 \\
5,06\end{array}$ \\
\hline Pisau foil I & Lognormal & $\begin{array}{l}\text { Shape } \\
\text { Location }\end{array}$ & $\begin{array}{l}0,33 \\
5,02 \\
\end{array}$ \\
\hline Pisau foil L & Normal & $\begin{array}{l}\text { Mean } \\
\text { Variance }\end{array}$ & $\begin{array}{r}161,90 \\
3260,54\end{array}$ \\
\hline $\begin{array}{l}\text { Pir pisau foil } \\
\text { I dan L }\end{array}$ & Lognormal & $\begin{array}{l}\text { Shape } \\
\text { Location }\end{array}$ & $\begin{array}{l}0,15 \\
5,82\end{array}$ \\
\hline
\end{tabular}

Contoh perhitungan parameter distribusi lognormal untuk komponen pir pisau foil I dan L, yaitu :

$$
\begin{gathered}
A\left(t_{i}\right)=e^{\mu+\frac{\sigma^{2}}{2}} \\
344=e^{\mu+\frac{\sigma^{2}}{2}} \\
\ln 344=\mu+\frac{\sigma^{2}}{2} \\
\left.\mu=5,8406-\frac{\sigma^{2}}{2} \text { (lalu substitusikan pada nilai } \mu \text { yang ada pada } \operatorname{Var}\left(t_{i}\right)\right)
\end{gathered}
$$


$\begin{aligned} \mu & =5,8406-\frac{0,02356}{2} \\ \mu & =5,828\end{aligned}$

$$
\operatorname{Var}\left(t_{i}\right)=e^{2 \mu+\sigma^{2}} x\left(e^{\sigma^{2}}-1\right)
$$

$2818,13=e^{2\left(5,8406-\frac{\sigma^{2}}{2}\right)+\sigma^{2}} x\left(e^{\sigma^{2}}-1\right)$

$2818,13=e^{11,6813} \times\left(e^{\sigma^{2}}-1\right)$

$2818,13=e^{11,6813} \times\left(e^{\sigma^{2}}-1\right)$

$2818,13=118193 x\left(e^{\sigma^{2}}-1\right)$

$0,02384=\left(e^{\sigma^{2}}-1\right)$

$e^{\sigma^{2}}=1,0284$

$\sigma^{2}=\ln 1,02384$

$\sigma^{2}=0,02356$

$\sigma=0,1535$

Dimana :

$A\left(t_{i}\right)$ adalah rata-rata time to failure

$\operatorname{Var}\left(t_{i}\right)$ adalah variansi time to failure

Nilai-nilai parameter diatas dapat digunakan untuk mencari keandalan komponen kritis mesin volpack.

5. Perhitungan keandalan komponen kritis

Setelah melakukan perhitungan parameter, langkah selanjutnya adalah melakukan perhitungan keandalan komponen kritis mesin volpack. Hasil dari perhitungan keandalan komponen kritis mesin volpack, dapat dilihat pada tabel 9.

Tabel 9. Perhitungan Keandalan Komponen Kritis

\begin{tabular}{lc}
\hline Komponen & Keandalan saat ini \\
\hline O-Ring & $1,46 \%$ \\
Klep pipa & $3,75 \%$ \\
Seal heater & $7,64 \%$ \\
Pisau foil I & $2,28 \%$ \\
Pisau foil L & $4,01 \%$ \\
Pir pisau foil I dan L & $7,64 \%$ \\
\hline
\end{tabular}

Contoh perhitungan keandalan komponen pir pisau foil I dan L, yaitu :

$$
\begin{aligned}
& R(t)=1-\Phi\left(\frac{1}{\sigma} \ln \frac{t}{t_{\text {med }}}\right) \\
& R(t)=1-\Phi\left(\frac{1}{\sigma} \ln \frac{t}{e^{\mu}}\right) \\
& R(t)=1-\Phi\left(\frac{1}{0,1535} \ln \frac{423,5}{2,718^{5,82885}}\right) \\
& R(t)=1-\Phi(1,43) \\
& R(t)=1-0,9236 \\
& R(t)=7,64 \%
\end{aligned}
$$

(Pers. 10)

(Pers. 11) 


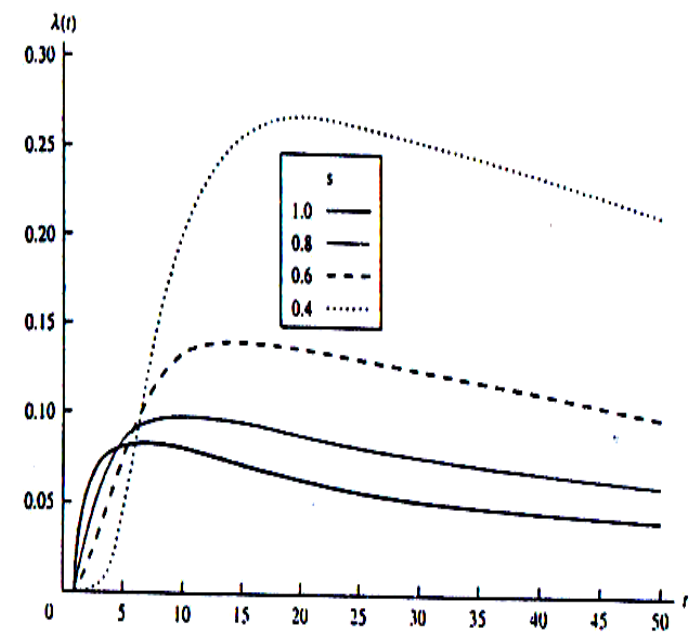

Gambar 5. Kurva Laju Kerusakan Lognormal

Dari Tabel 9 dapat dilihat bahwa keandalan komponen kritis mesin volpack kurang dari $10 \%$, sehingga dapat disimpulkan bahwa keandalan komponen kritis mesin volpack sangat rendah.

Penerapan preventive maintenance bisa diterapkan pada komponen yang memiliki laju kerusakan yang terus meningkat sehingga dengan adanya preventive maintenance, keandalan mesin dan komponen bisa ditingkatkan. Untuk distribusi lognormal, jika nilai $\sigma$ semakin kecil, maka laju kerusakan komponen tersebut akan semakin meningkat sehingga kegiatan preventive maintenance bisa diterapkan. Tabel 6 menunjukkan parameter bentuk dari setiap distribusi.

Tabel 10. Parameter Scale Distribusi Lognormal

\begin{tabular}{lc}
\hline Komponen & Nilai parameter \\
\hline Klep pipa & $\sigma=0,2755$ \\
Seal heater & $\sigma=0,4787$ \\
Pisau foil I & $\sigma=0,3301$ \\
Pir pisau foil I dan L & $\sigma=0,1535$ \\
\hline
\end{tabular}

Pada gambar 5 diketahui nilai parameter bentuk atau $\sigma$ yang berdistribusi lognormal jika bernilai kurang dari 1 akan menyebabkan kerusakan yang dialami komponen ini akan semakin meningkat dan menyebabkan komponen tersebut mempunyai laju kerusakan yang semakin memuncak.

Pada tabel 6 diketahui bahwa nilai $\sigma$ bernilai kurang dari 1 yaitu 0,$2755 ; 0,4787 ; 0,33016 ; 01535$ sehingga dapat disimpulkan bahwa komponen-komponen tersebut mempunyai laju kerusakan yang semakin meningkat. Oleh karena itu, kegiatan perawatan preventive maintenance dapat diterapkan.

\section{Analisis Tingkat Keandalan}

Keandalan adalah probabilitas suatu komponen atau mesin dapat bekerja sebagaimana mestinya atau sesuai yang diharapkan. Pada tabel 7 diketahui bahwa keandalan komponen saat ini yaitu sebelum diterapkan preventive maintenance adalah kurang dari $10 \%$. Hal ini dikarenakan bahwa komponen-komponen tersebut sering mengalami kerusakan secara tiba-tiba dalam jarak waktu yang relatif singkat sehingga menimbulkan penurunan dari nilai keandalan komponen tersebut. Selain itu, nilai reliability (keandalan) dipengaruhi oleh waktu yang artinya semakin panjang waktu penggunaan komponen-komponen tersebut, maka nilai keandalannya akan semakin menurun.

Oleh karena itu, jika diterapkan preventive maintenance, maka nilai keandalan dari komponen tersebut akan meningkat. Jadi, jika perusahaan ingin meningkatkan keandalan dari komponen tersebut, maka perusahaan bisa melakukan preventive maintenance dengan menerapkan jadwal interval pergantian komponen berdasarkan tingkat keandalan yang diinginkan oleh perusahaan. Dengan menerapkan preventive maintenance, perusahaan bisa mengurangi frekuensi downtime mesin yang terjadi, menurunkan jumlah produk cacat dan meningkatkan kapasitas produksi mesin.

Karena nilai keandalan dipengaruhi oleh waktu, maka jika perusahaan ingin mendapatkan keandalan yang lebih tinggi dari keandalan saat ini, maka perusahaan bisa menggunakan interval perawatan preventive maintenance. 
Analisis Penyebab Kerusakan Pada Komponen Kritis

Ada banyak faktor yang mempengaruhi tingkat frekuensi kerusakan dari komponen tersebut, antara lain :

a. O-Ring

O-Ring adalah komponen berbentuk cincin yang sangat lunak yang terbuat dari bahan alam atau karet synthetic. Komponen O-Ring ini terdapat pada perfume doser. Komponen ini berfungsi untuk menahan gaya tekan yang diberikan perfume doser yang setiap saat harus menyalurkan cairan cologne ke atas agar cairan tersebut masuk ke dalam kemasan tissue.

Penyebab komponen ini cepat mengalami kerusakan adalah kapasitas produksi yang dapat dihasilkan mesin ini besar. Dalam 1 menit, mesin ini bisa menghasilkan 120 tissue basah, sehingga dalam 1 menit komponen ini menerima 120 tekanan yang diberikan dari perfume doser. Tentu saja O-Ring yang terbuat dari karet, jika terlalu lama menahan dan menerima tekanan yang diberikan perfume doser secara terus menerus pasti akan mengalami kelenturan sehingga menjadi cepat putus.

Selain itu, proses putusnya O-Ring disebabkan oleh dinding dalam perfume doser mengalami karat karena terlalu sering bersentuhan dengan cairan cologne sehingga membuat ketebalan dinding perfume doser menjadi menebal. Akibatnya, O-Ring yang mengalami gaya tekan ke atas akan terus menerus bergesekan dengan dinding perfume doser yang berkarat, sehingga membuat O-Ring menjadi putus. Dampak yang dihasilkan adalah perfume doser memompa cairan cologne yang tidak sesuai dengan takaran perusahaan dan menyebabkan adanya cairan cologne yang tumpah.

Untuk menjaga agar komponen ini tidak cepat mengalami kerusakan, perusahaan sebaiknya melakukan pembersihan pada dinding perfume doser agar karat yang berada pada dinding perfume doser berkurang atau menghilang.

b. $\quad$ Klep pipa

Komponen ini berfungsi untuk menahan selang agar dapat tetap menyalurkan cairan cologne ke atas agar bisa masuk ke dalam kemasan. Komponen ini terletak pada bagian atas perfume doser. Komponen ini sering mengalami kerusakan karena terlalu sering menahan beban tekan yang diberikan oleh perfumedoser ke dalam selang dan disertai dengan pemasangan yang terlalu kencang sehingga, jika komponen ini secara terus menerus menahan gaya tekan yang terlalu lama, komponen ini pasti akan mengalami crack lalu patah.

Selain itu, komponen ini juga sering terkena cairan cologne yang keluar dari pipa sehingga menyebabkan komponen ini cepat mengalami karat dan membuat komponen ini menjadi cepat patah.

c. Seal heater

Seal heater adalah komponen yang berfungsi untuk melakukan sealing dengan cara menahan pada suhu panas yang bertujuan untuk merekatkan bagian atas dari kemasan tissue. Suhu panas yang muncul dari seal heater berasal dari energi listrik yang disalurkan melalui batangan besi yang dimasukkan ke dalam seal heater. Tingkat frekuensi kerusakan yang tinggi dari seal heater disebabkan oleh cairan cologne dan air yang sering mengenai permukaan seal heater dan menyebabkan terjadinya konsleting pada batangan besi tersebut. Konsleting terjadi karena air menyebabkan suhu pada permukaan seal heater semakin naik dan perlu dilakukan setting ulang untuk mengatur panasnya kembali sehingga seal heater bisa merekatkan kemasan tissue basah.

\section{d. $\quad$ Pisau foil I dan $L$}

Pisau foil I dan L adalah komponen yang berfungsi untuk memotong tissue basah cologne yang sudah jadi dan siap di package. Komponen ini sering mengalami kerusakan akibat terlalu seringnya memotong plastik. Komponen ini adalah berupa logam yang dimana akan mudah tumpul jika terkena sering terkena udara dan terlalu banyak memotong plastik dengan ketebalan yang berbeda-beda.

e. $\quad$ Per Pisau Foil I dan L

Per pisau foil I dan L adalah komponen yang berfungsi untuk menggerakkan pisau foil I dan L agar dapat memotong tissue. Komponen ini dalam 1 menit bisa menerima gaya tarik sebanyak 120 kali, sesuai dengan hasil produksi mesin volpack. Dengan frekuensi gaya tarik yang tinggi dengan gaya yang konstan, lama kelamaan komponen ini mengalami fatigue dan menyebabkan komponen ini mengalamipatah.

Gambar 6 menjelaskan mengenai gaya tarik yang diterima oleh suatu logam. Jika suatu logam mengalami gaya tarik secara terus menerus, maka suatu saat logam itu pasti akan mencapai titik luluh dan mencapai titik tegangan maksimum sehingga benda tersebut cepat mengalami patah atau putus. Logam pada awalnya akan bisa kembali ke bentuk semula saat diberi suatu gaya, namun lama kelamaan logam tersebut akan mengalami deformasi plastis yang dimana logam tersebut tidak akan bisa kembali ke bentuk semula dan jika masih diberi gaya, logam tersebut akan mengalami patah dan kemudian menjadi putus. 


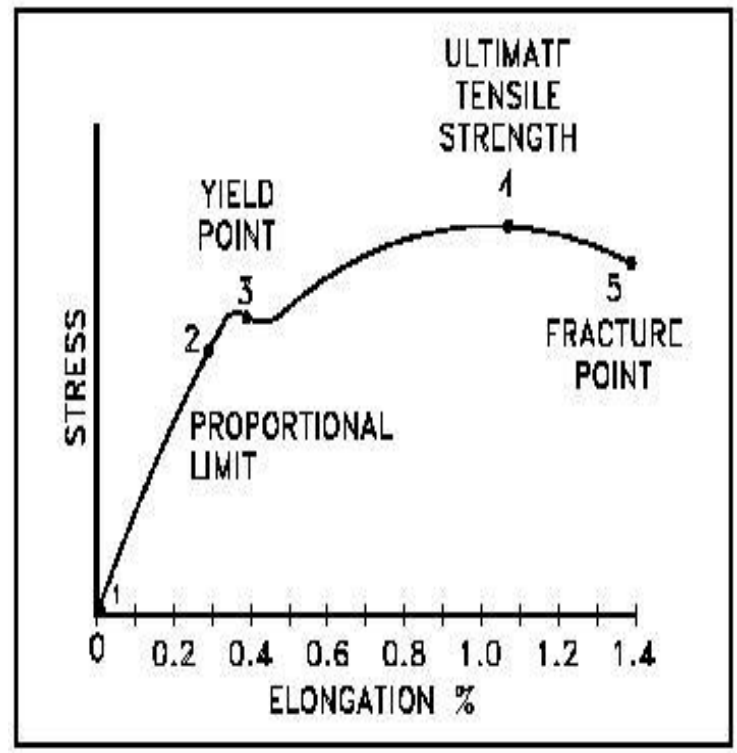

Gambar 6. Gaya Tarik Logam

Begitupula dengan komponen ini, jika sudah mencapai titik lelah dan mencapai titik tegangan maksimum, jika masih diberi gaya tarik yang konstan secara terus menerus, tentu saja komponen ini akan mengalami fatigue sehingga patah.

\section{Analisis Keandalan Mesin}

Keandalan mesin sangat berkaitan erat dengan keandalan komponennya. Keandalan mesin volpack didapatkan yaitu $0,000000459 \%$. Hal ini dikarenakan semua komponen kritis mempunyai keandalan dibawah $10 \%$. Dengan nilai keandalan komponen kritis mesin ini yang rendah, maka akan dipastikan keandalan mesin juga rendah.

Jika perusahaan menginginkan keandalan mesin meningkat, maka perusahaan bisa melakukan preventive maintenance dengan menerapkan waktu interval perawatan. Dengan demikian, keandalan komponen dapat meningkat.

\section{Rekomendasi Perbaikan}

Rekomendasi yang dapat diberikan oleh peneliti kepada perusahaan adalah dengan melakukan perawatan yang lebih baik, yaitu dengan menerapkan preventive maintenance.

Preventive maintenance yang dilakukan bisa bersifat pergantian komponen kritis berdasarkan waktu interval tertentu. Dengan preventive maintenance, perusahaan bisa mencegah terjadinya downtime tiba-tiba. Dengan demikian, perusahaan bisa meminimasi perbedaan target produksi dengan hasil produksi yang nyata. Selain itu, dengan adanya preventive maintenance, perusahaan bisa melakukan minimasi terhadap barang cacat yang dihasilkan.

Bentuk preventive maintenance yang bisa diterapkan adalah dengan melakukan pergantian komponen untuk komponen klep pipa, pisau foil I dan L, Pir pisau foil I dan L dan bentuk preventive maintenance yang bisa diterapkan pada komponen seal heater adalah dengan melakukan setting ulang panas pada komponen tersebut. Pada komponen O-Ring, bentuk kegiatan preventive maintenance yang bisa diterapkan adalah dengan melakukan kalibrasi pada perfume doser agar O-Ring tidak menjadi cepat putus.

\section{KESIMPULAN}

Berdasarkan hasil dan pembahasan yang dilakukan peneliti, kesimpulan yang dapat diambil antara lain :

1. Pola kerusakan dari komponen mesin volpack terus meningkat. Hal ini ditunjukkan dengan nilai parameter bentuk (shape) dari distribusi lognormal yang bernilai kurang dari 1 yaitu komponen klep pipa dengan nilai 0,0759; komponen seal heater dengan nilai 0,02291; komponen pisau foil I dengan nilai 0,1090; komponen pisau foil $\mathrm{L}$ dengan nilai 0,1265 ; komponen per pisau foil I dan $\mathrm{L}$ dengan nilai 0,0235 .

2. Pada kondisi saat ini diketahui bahwa nilai keandalan untuk komponen kritis mesin volpack antara lain komponen O-Ring sebesar 1,46 \%; komponen klep pipa sebesar 3,75\%; komponen seal heater sebesar $7,64 \%$; komponen pisau foil I sebesar 2,28\% ; komponen pisau foil L sebesar 4,01\% ; dan komponen pir pisau foil I dan L sebesar 7,64\%. 


\section{DAFTAR PUSTAKA}

[1] AHYARI, AGUS, (2002), Manajemen Produksi, Yogyakarta: FE UGM.

[2] ASSAURI, SOFYAN, (2004), Manajemen Produksi dan Operasi, Jakarta: Lembaga Penerbit Fakultas Ekonomi UI.

[3] AZWAR, SAIFUDDIN, (1997), Metode Penelitian, Yogyakarta: Pustaka Pelajar.

[4] BLANCARD, ANTONY, (1996), Teknik Manajemen Pemeliharaan, Jakarta: Erlangga.

[5] CORDER, ANTONY, (1996), Teknik Manajemen Pemeliharaan, Jakarta: Erlangga.

[6] DHILLON, B, S, (2002), Engineering Maintenance a Modern Approach, New York: Boca RatonCRC Press.

[7] EBELLING, (1997), Reliability and Maintainability Engineering, Singapore : McGraw-Hill Company

[8] LEWIS, E,E, (1996), Introduction to Reliability Engineering Second edition, John Wiley and Sons Inc, New York.

[9] MOUBRAY, JOHN, (1991), Reliability Centered Maintenance II, London: Butterworth - HeinemannLtd.

[10] PARTINO R \& IDRUS M, (2010), Statistik Inferensial, Yogyakarta: Safiria Insania Press.

[11] RAUSAND, MARVIN, (2004), System Reliability Theory, Second Edition, USA: Wiley Inerscience.

[12] SUDRAJAT, ATING, (2011), Manajemen Perawatan Mesin Industri, Bandung : Refika Aditama 